\title{
PENGARUH SISTEM OLAH TANAH DAN PEMUPUKAN NITROGEN TERHADAP KEANEKARAGAMAN DAN POPULASI MESOFAUNA PADA SERASAH TANAMAN PADI GOGO (Oryza sativa L.) MUSIM TANAM KE-46
}

\author{
Annisa Ika Pratiwi Harahap, Muhajir Utomo, Sri Yusnaini \& Syamsul Arif \\ Jurusan Agroteknologi Fakultas Pertanian Universitas Lampung \\ Jl. Prof. Soemantri Brodjonegoro, No 1 Bandar Lampung \\ Email: annisapratiwi10@yahoo.co.id
}

\begin{abstract}
ABSTRAK
Penelitian ini bertujuan untuk mempelajari pengaruh sistem olah tanah, pemberian pupuk nitrogen, dan kombinasi antara sistem olah tanah dan pemupukan nitrogen terhadap populasi dan keanekaragaman mesofauna serasah tanaman padi gogo (Oryza sativa L.). Penelitian ini merupakan tahun ke-27 yang dilaksanakan pada bulan November 2014 sampai dengan bulan Maret 2015 di Politeknik Negeri Lampung. Penelitian dilakukan menggunakan rancangan acak kelompok (RAK), disusun secara faktorial 3x2 dengan 4 ulangan. Faktor pertama yaitu perlakuan sistem olah tanah yakni $\mathrm{T}_{0}=\mathrm{TOT}(\operatorname{tanpa}$ olah tanah), $\mathrm{T}_{1}=\mathrm{OTM}$ (olah tanah minimum), dan $\mathrm{T}_{2}=\mathrm{OTI}$ (olah tanah intensif), sedangkan faktor kedua yaitu pemupukan nitrogen (N) jangka panjang (1987), yaitu $\mathrm{N}_{0}$ (tanpa pupuk $\mathrm{N}$ ) dan $\mathrm{N}_{1}\left(100 \mathrm{~kg} \mathrm{~N} \mathrm{ha}^{-1}\right)$. Pengambilan sampel mesofauna serasah dilakukan sebanyak 2 kali yaitu pada saat sebelum tanam dan setelah panen. Hasil penelitian menunjukkan bahwa populasi mesofauna serasah lahan tanpa olah tanah $\left(\mathrm{T}_{0}\right)$ lebih tinggi daripada olah tanah minimum $\left(\mathrm{T}_{1}\right)$ dan olah tanah intensif $\left(\mathrm{T}_{2}\right)$, sedangkan keanekaragaman mesofauna lebih tinggi pada olah tanah intensif $\left(\mathrm{T}_{2}\right)$ daripada tanpa olah tanah $\left(\mathrm{T}_{0}\right)$ dan olah tanah minimum $\left(\mathrm{T}_{1}\right)$. Populasi mesofauna serasah dengan pemupukan nitrogen $100 \mathrm{~kg} \mathrm{~N} \mathrm{ha}^{-1}\left(\mathrm{~N}_{1}\right)$ lebih tinggi daripada tanpa pemupukan nitrogen $\left(\mathrm{N}_{0}\right)$, sedangkan pemupukan nitrogen $100 \mathrm{~kg} \mathrm{~N} \mathrm{ha}^{-1}$ tidak berpengaruh terhadap keanekaragaman mesofauna serasah. Tidak terdapat interaksi antara sistem pengolahan tanah dan pemupukan nitrogen terhadap populasi dan keanekaragaman mesofauna serasah. Pada seluruh perlakuan, Indeks Keanekaragaman (H') mesofauna serasah menurut kategori ShannonWeaver termasuk dalam kategori rendah dan Acarina merupakan ordo mesofauna yang mendominasi. Peningkatan biomassa serasah dapat meningkatkan populasi mesofauna serasah, namun menurunkan Indeks Keanekaragaman (H') mesofauna serasah. Selain itu, peningkatan kadar air tanah juga dapat meningkatkan populasi mesofauna serasah.
\end{abstract}

Kata kunci: mesofauna, nitrogen, olah tanah, pemupukan, serasah.

\section{PENDAHULUAN}

Padi merupakan bahan pangan terpenting di Indonesia mengingat makanan pokok penduduk Indonesia sebagian besar adalah beras. Sementara itu, areal pertanian di lahan sawah terus berkurang seiring perkembangan dan pembangunan di bidang industri, sehingga diperlukan pembukaan lahan baru, termasuk lahan kering. Menurut Prasetyo (2007) lahan kering Indonesia didominasi oleh jenis tanah Podsolik Merah Kuning (PMK) dengan kondisi topografi bergelombang, mudah tererosi, miskin unsur hara, tingkat kemasaman yang tinggi, dan bahan organik tanah yang mudah sekali turun kadarnya jika lahan tersebut terus diusahakan. Selama ini, sistem olah tanah intensif (OTI) lebih banyak diterapkan dalam penyiapan lahan. Belakangan ini diketahui bahwa cara penyiapan lahan tersebut ditinjau dari aspek ekonomi maupun aspek kelestarian lingkungan (konservasi) banyak menimbulkan kerugian (Prasetyo, 2007). Penyebab utama degradasi tanah di Indonesia adalah erosi oleh air, pencucian hara, dan pemadatan tanah oleh alat-alat berat yang sebagian besar disebabkan oleh pengolahan tanah intensif (Utomo, 2012). Oleh karena itu, diperlukan pengolahan tanah yang dapat meningkatkan produktivitas tanah, mengurangi degradasi tanah sekaligus dapat mengurangi kebutuhan tenaga kerja dan waktu persiapan lahan (Utomo, 2012).

Pada dasarnya, setiap tindakan pengolahan tanah akan mempengaruhi kesuburan tanah sehingga akan berpengaruh terhadap biota tanah, baik dari jenis flora maupun fauna tanah. Sugiyarto dkk. (2001) mengatakan bahwa beberapa jenis fauna tanah dapat digunakan sebagai petunjuk atau indikator terhadap kesuburan tanah. Mesofauna merupakan kelompok fauna tanah terbesar yang menetap di atas permukaan maupun di 
dalam tanah dibandingkan dengan fauna tanah lainnya. Mesofauna yang paling penting keberadaannya yaitu Collembola dan Acarina. Mesofauna merupakan salah satu organisme tanah yang memanfaatkan bahan organik sebagai sumber makanannya. Selain sebagai konsumen, mesofauna juga berperan sebagai pengurai dalam proses pelapukan dan pemecahan bahan-bahan organik tanah.

Pemberian unsur hara nitrogen $(\mathrm{N})$ ke dalam tanah penting terhadap pemeliharaan dan peningkatan kesuburan tanah yang nantinya akan berpengaruh terhadap pertumbuhan dan produksi tanaman. Kebutuhan $\mathrm{N}$ untuk pertumbuhan tanaman tidak tersedia begitu saja dan $\mathrm{N}$-organik yang berada dalam tanah tidak cukup dalam memenuhi kebutuhan tanaman. Kegiatan pemupukan dapat mempengaruhi biomassa serasah sehingga akan berpengaruh terhadap keberadaan biota tanah khususnya mesofauna. Mesofauna sangat sensitif terhadap perubahan vegetasi dan lingkungan. Jumlah dan keanekaragaman mesofauna berbanding lurus dengan lingkungan yang mendukung untuk tumbuh dan berkembangbiak (Sugiyarto dkk., 2001).

\section{BAHAN DAN METODE}

Penelitian ini merupakan tahun ke-27 musim tanam ke-46, yang dilaksanakan pada bulan November 20146 Maret 2015. Penanaman dilakukan di lahan Politeknik Negeri Lampung. Analisis contoh tanah dan serasah dilakukan di Laboratorium Ilmu Tanah, Fakultas Pertanian, Universitas Lampung.

Penelitian ini dilakukan menggunakan rancangan acak kelompok (RAK), disusun secara faktorial 3x2 dengan 4 ulangan. Faktor pertama yaitu perlakuan sistem olah tanah yaitu $\mathrm{T}_{0}=$ TOT $\left(\operatorname{tanpa}\right.$ olah tanah), $\mathrm{T}_{1}=\mathrm{OTM}$ (olah tanah minimum), dan $\mathrm{T}_{2}=\mathrm{OTI}$ (olah tanah intensif), sedangkan faktor kedua yaitu pemupukan nitrogen $(\mathrm{N})$ jangka panjang, yaitu $\mathrm{N}_{0}$ (tanpa pupuk $\left.\mathrm{N}\right)$ dan $\mathrm{N}_{1}(100$ $\mathrm{kg} \mathrm{N} \mathrm{ha}^{-1}$ ). Data yang diperoleh diuji homogenitasnya menggunakan uji Bartlett dan aditifitasnya menggunakan uji Tukey, kemudian perbedaan nilai tengah diuji menggunakan BNT taraf 5\%.

Selain itu, aplikasi pupuk $\mathrm{KCl}$ dan SP-18 juga dilakukan sebanyak $100 \mathrm{~kg} \mathrm{KCl} \mathrm{ha}^{-1}$ dan $150 \mathrm{~kg} \mathrm{SP}-18$ $\mathrm{ha}^{-1}$. Pemeliharaan dilakukan dengan penyulaman, penyiraman, penyiangan gulma, serta pengendalian hama penyakit bila diperlukan. Pemanenan dilakukan jika 90\% malai sudah menguning, batang mengering, dan gabah sudah keras. Pengambilan sampel mesofauna pada serasah dilakukan sebanyak 2 kali yaitu pada saat sebelum tanam (komposit berdasarkan ulangan) dan setelah panen (semua ulangan). Pengambilan serasah dilakukan menggunakan bingkai kayu berukuran $50 \mathrm{~cm}$ x $50 \mathrm{~cm}$ di setiap titik yang ditentukan secara acak. Selanjutnya ditimbang $100 \mathrm{~g}$ serasah untuk diekstraksi menggunakan corong Barlese Tullgren. Serasah tersebut disinari di bawah lampu 15 watt selama 48 jam. Keanekaragaman mesofauna diidentifikasi menurut buku Introduction of Insect (Borror dkk., 1997). Populasi mesofauna dihitung menggunakan mikroskop stereo perbesaran 20640 kali. Prosedur tersebut merujuk pada penuntun praktikum Biologi dan Kesehatan Tanah oleh Niswati dkk. (2013). Populasi mesofauna dihitung dengan cara:

$$
\text { Total Populasi }=\frac{\text { Jumlah individu (ekor) }}{\text { Bobot kering serasah }(100 \mathrm{~g})}
$$

Keanekaragaman mesofauna serasah berdasarkan ordo masing-masing dihitung menggunakan Indeks Keanekaragaman (H') Shannon-Weaver (Odum, 1983) dengan rumus sebagai berikut:

$$
\mathrm{H}^{\prime}=-\sum[(\mathrm{ni} / \mathrm{N}) \ln (\mathrm{ni} / \mathrm{N})]
$$

Keterangan:

H' = Indeks keanekaragaman Shannon-Weaver

$\mathrm{ni}=$ Jumlah individu jenis ke- $\mathrm{i}$

$\mathrm{N}=$ Jumlah total individu yang ditemukan

Variabel utama yang diamati adalah populasi mesofauna pada serasah (ekor $100 \mathrm{~g}^{-1}$ ). dan keanekaragaman mesofauna pada serasah (tinggi, sedang, atau rendah). Sedangkan variabel pendukung yang diamati adalah C-organik serasah (\%), N-total serasah (\%), biomassa serasah (g), $\mathrm{pH}$ tanah, kadar air tanah $(\%)$, dan suhu tanah $\left({ }^{\circ} \mathrm{C}\right)$.

\section{HASIL DAN PEMBAHASAN}

Hasil pengamatan populasi mesofauna serasah komposit, mesofauna serasah sebelum tanam (awal) banyak dijumpai pada perlakuan olah tanah minimum tanpa pemberian pupuk nitrogen $\left(\mathrm{T}_{1} \mathrm{~N}_{0}\right)$, sedangkan pada perlakuan olah tanah intensif dengan residu pemupukan nitrogen $100 \mathrm{~kg} \mathrm{~N}^{-1}\left(\mathrm{~T}_{2} \mathrm{~N}_{1}\right)$ populasi mesofauna serasah sedikit (Gambar 1). Hal ini diduga karena serasah yang merupakan substrat dan sumber bahan makanan bagi mesofauna lebih tinggi pada olah tanah minimum (OTM) dibandingkan tanpa olah tanah (TOT) dan olah tanah intensif (OTI). Selain itu, olah tanah minimum (OTM) memiliki porositas dan aerasi tanah lebih baik daripada tanpa olah tanah (TOT) berpengaruh terhadap keberadaan mesofauna. Mesofauna membutuhkan sirkulasi udara bernafas. 
Mesofauna juga banyak dijumpai pada tanah bagian atas dan hidup pada ruang pori-pori tanah yang telah ada karena mesofauna tidak dapat membuat lubang sendiri. Lebih lanjut, tanpa pemberian pupuk nitrogen diduga dapat memperlambat proses dekomposisi serasah, yang mengakibatkan sumber makanan bagi mesofauna terjamin lebih lama sehingga mesofauna lebih tahan untuk tetap tinggal di lahan tersebut (Sugiarto, 2000).

Gambaran umum hasil pengamatan populasi mesofauna serasah setelah panen (akhir) banyak dijumpai pada perlakuan tanpa olah tanah dengan pemupukan nitrogen $100 \mathrm{~kg} \mathrm{~N} \mathrm{ha}^{-1}\left(\mathrm{~T}_{0} \mathrm{~N}_{1}\right)$, sedangkan pada perlakuan olah tanah intensif dengan tanpa pemupukan nitrogen $\left(\mathrm{T}_{2} \mathrm{~N}_{0}\right)$ populasi mesofauna serasah sedikit (Gambar 1). Hal ini diduga karena serasah yang merupakan substrat dan sumber bahan makanan bagi mesofauna lebih tinggi pada tanpa olah tanah (TOT) dibandingkan olah tanah minimum (OTM) dan olah tanah intensif (OTI). Selain itu, pemberian pupuk nitrogen $100 \mathrm{~kg} \mathrm{~N} \mathrm{ha}^{-1}$ diduga dapat meningkatkan biomassa serasah sehingga populasi mesofauna meningkat.

Pada semua perlakuan, ordo Acarina merupakan jenis mesofauna yang mendominasi, disusul oleh ordo Collembola, dan lain-lain (Gambar 1). Hal ini diduga karena Acarina berperan langsung terhadap proses dekomposisi serasah yakni mempercepat proses penghancuran serasah, sedangkan sumber energi Collembola berasal dari bahan organik yang telah terdekomposisi di dalam tanah (Nelfa, 2000). Hal tersebut sesuai dengan hasil penelitian Guevara (2002) menyebutkan bahwa mesofauna yang mendominasi pada serasah Hutan Tropika Santuario del Bosque de Niebla Mexico adalah ordo Acarina, sedangkan pada tanah adalah ordo Collembola. Hasil pengamatan Indeks Keanekaragaman (H') mesofauna serasah sebelum tanam, berdasarkan kategori Shannon-Weaver termasuk dalam kategori rendah pada semua perlakuan (Tabel 1). Hal ini diduga karena keadaan ekosistem yang kurang seimbang. Hal tersebut juga dikatakan oleh Foth (1998) bahwa tingkat keragaman mesofauna ditentukan oleh ketersediaan energi dan kapasitas ekologi lingkungan. Pada lahan penelitian, dilakukan analisis beberapa sifat fisik dan kimia contoh tanah maupun serasah sebelum tanam (awal). Hasil pengamatan analisis $\mathrm{pH}$ tanah memberikan nilai yang rentangnya tidak jauh berbeda antara perlakuan yang satu dan yang lainnya yakni pada $\mathrm{pH} 5$, begitu juga dengan kadar air tanah dan suhu tanah. Kadar air tanah yang didapatkan berkisar $6 \%$, sedangkan suhu tanah yang didapatkan berkisar $30-31^{\circ} \mathrm{C}$.

Tabel 1. Indeks keanekaragaman ( $\left.\mathrm{H}^{\prime}\right)$ mesofauna serasah sebelum tanam (awal).

\begin{tabular}{ccc}
\hline Perlakuan & $\begin{array}{c}\text { Indeks } \\
\text { Keanekaragaman } \\
\left(\mathrm{H}^{\prime}\right)\end{array}$ & $\begin{array}{c}\text { Kategori } \\
\text { (Shannon- } \\
\text { Weaver })\end{array}$ \\
\hline $\mathrm{T}_{0} \mathrm{~N}_{0}$ & 0,81 & Rendah \\
$\mathrm{T}_{0} \mathrm{~N}_{1}$ & 0,51 & Rendah \\
$\mathrm{T}_{1} \mathrm{~N}_{0}$ & 0,45 & Rendah \\
$\mathrm{T}_{1} \mathrm{~N}_{1}$ & 0,86 & Rendah \\
$\mathrm{T}_{2} \mathrm{~N}_{0}$ & 0,39 & Rendah \\
$\mathrm{T}_{2} \mathrm{~N}_{1}$ & 1,02 & Rendah \\
\hline
\end{tabular}

Keterangan : $\mathrm{T}_{0}=$ tanpa olah tanah $(\mathrm{TOT}), \mathrm{T}_{1}=$ olah tanah minimum (OTM), $\mathrm{T}_{2}=$ olah tanah intensif (OTI), $\mathrm{N}_{0}=$ tanpa pupuk $\mathrm{N}$, $\mathrm{N}_{1}=$ residu pemupukan $\mathrm{N} 100 \mathrm{~kg} \mathrm{~N} \mathrm{ha}^{-1}$.

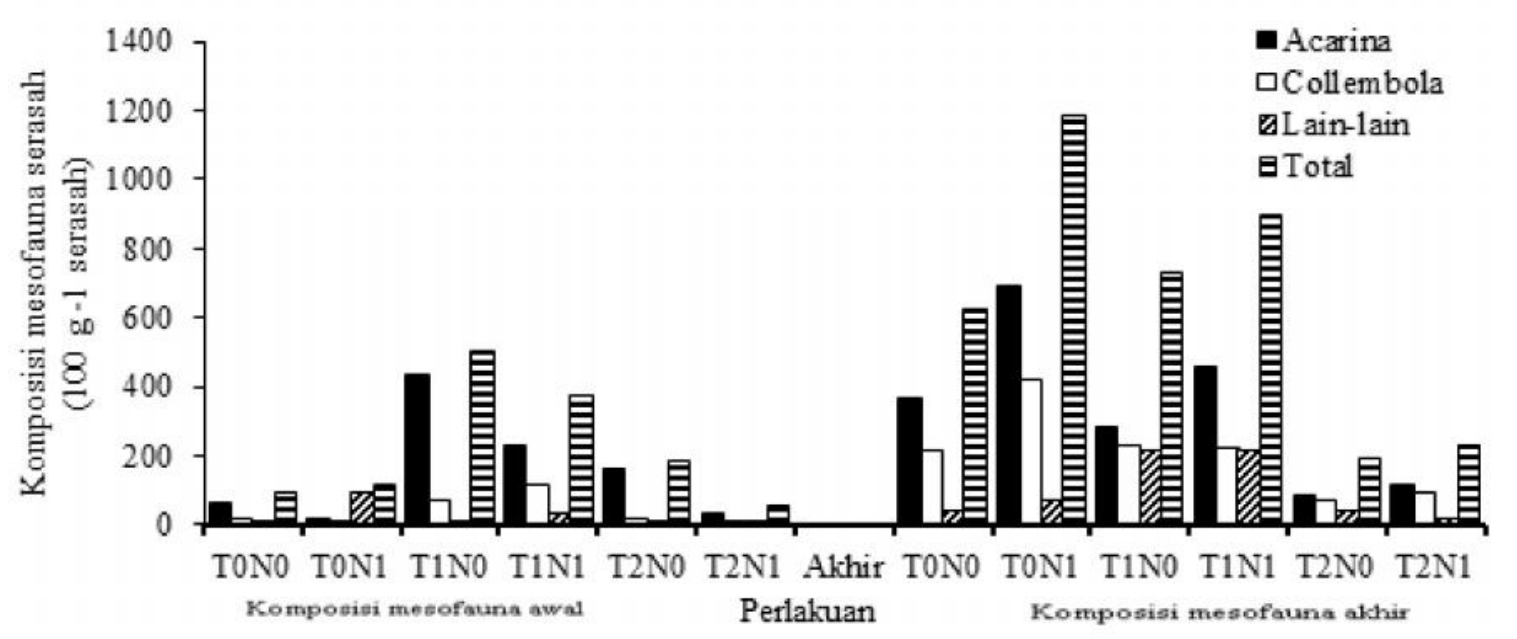

Gambar 1. Komposisi mesofauna serasah sebelum tanam (awal) dan komposisi mesofauna serasah setelah panen (akhir). $\mathrm{T}_{0}=$ tanpa olah tanah (TOT), $\mathrm{T}_{1}=$ olah tanah minimum (OTM), $\mathrm{T}_{2}=$ olah tanah intensif $(\mathrm{OTI})$, $\mathrm{N}_{0}=$ tanpa pupuk $\mathrm{N}, \mathrm{N}_{1}=$ residu pemupukan $\mathrm{N} 100 \mathrm{~kg} \mathrm{~N}$ ha $^{-1}$. 
Hasil uji korelasi menunjukkan bahwa suhu tanah sebelum tanam (awal) berkorelasi negatif dengan populasi mesofauna serasah sebelum tanam (awal) (Tabel 2). Suhu optimal bagi mesofauna yakni $15-25^{0}$ $\mathrm{C}$, sedangkan suhu tanah saat pengambilan sampel serasah berkisar $30-31{ }^{\circ} \mathrm{C}$ diduga, hanya sedikit mesofauna yang bertahan hidup sehingga mesofauna bermigrasi ke tempat lain yang lebih lembab. Hal ini sesuai dengan hasil penelitian Gede (2006) yang menyatakan bahwa jumlah mesofauna yang didapatkan pada suhu $29-30{ }^{\circ} \mathrm{C}$ tergolong rendah. Lebih lanjut, hasil uji korelasi menunjukkan bahwa biomassa serasah, pH tanah dan kadar air tanah sebelum tanam (awal) tidak berkorelasi dengan populasi mesofauna serasah sebelum tanam (awal) (Tabel 2). Hasil uji korelasi menunjukkan bahwa biomassa serasah, $\mathrm{pH}$ tanah, kadar air tanah dan suhu tanah sebelum tanam (awal) tidak berkorelasi dengan Indeks Keanekaragaman (H') mesofauna serasah sebelum tanam (awal) (Tabel 2).

Hasil analisis ragam populasi mesofauna serasah menunjukkan bahwa sistem olah tanah maupun pemupukan nitrogen berpengaruh terhadap populasi mesofauna dan biomassa serasah setelah panen (akhir), namun tidak terdapat interaksi antara sistem olah tanah dan pemupukan nitrogen terhadap populasi mesofauna dan biomassa serasah (Tabel 3).

Hasil uji lanjut BNT taraf $5 \%$ menunjukkan bahwa tanpa olah tanah $\left(\mathrm{T}_{0}\right)$ merupakan sistem pengolahan tanah yang dapat menghasilkan populasi mesofauna lebih banyak daripada olah tanah minimum $\left(\mathrm{T}_{1}\right)$ dan olah tanah intensif $\left(\mathrm{T}_{2}\right)$ (Tabel 4). Hal ini diduga karena tanpa olah tanah memiliki mulsa yang lebih tinggi dibandingkan olah tanah minimum (OTM) dan olah tanah intensif (OTI). Hal ini sesuai dengan hasil uji lanjut BNT taraf 5\% biomassa serasah setelah panen (akhir), bahwa tanpa olah tanah $\left(\mathrm{T}_{0}\right)$ merupakan sistem pengolahan tanah yang dapat menghasilkan biomassa serasah yang lebih tinggi dibandingkan olah tanah minimum $\left(\mathrm{T}_{1}\right)$ dan olah tanah intensif $\left(\mathrm{T}_{2}\right)$ (Tabel 4).

Hasil uji lanjut BNT taraf 5\% antara pemupukan $\mathrm{N}$ dengan populasi mesofauna serasah menunjukkan bahwa pemupukan nitrogen $100 \mathrm{~kg} \mathrm{~N} \mathrm{ha}^{-1}\left(\mathrm{~N}_{1}\right)$ menghasilkan populasi mesofauna serasah lebih banyak daripada tanpa pemupukan nitrogen $\left(\mathrm{N}_{0}\right)$ (Tabel 4). Pemberian pupuk nitrogen $100 \mathrm{~kg} \mathrm{~N}^{-1}$ setelah penanaman diduga dapat meningkatkan mesofauna pada serasah, karena pemberian pupuk nitrogen dapat meningkatkan biomassa serasah. Hal ini sesuai dengan hasil uji lanjut BNT taraf 5\% biomassa serasah setelah panen (akhir), pemupukan nitrogen $100 \mathrm{~kg} \mathrm{~N} \mathrm{ha}^{-1}$ menghasilkan biomassa serasah lebih tinggi daripada tanpa pemupukan nitrogen (Tabel 4). Hal ini dikemukakan juga oleh Yudin (2012), jumlah Acarina dan Collembola pada lahan pertanaman Tebu (Saccharum officinarum L.) lebih tinggi pada perlakuan yang diberi input pupuk nitrogen.

Hasil analisis ragam Indeks Keanekaragaman (H') mesofauna serasah menunjukkan bahwa sistem olah tanah berpengaruh terhadap Indeks Keanekaragaman (H') mesofauna serasah, namun pemupukan nitrogen tidak berpengaruh terhadap Indeks Keanekaragaman (H') mesofauna serasah, dan tidak terdapat interaksi antara sistem pengolahan tanah dan pemupukan nitrogen terhadap Indeks Keanekaragaman (H') mesofauna serasah (Tabel 5). Hasil uji lanjut BNT taraf $5 \%$ menunjukkan bahwa olah tanah intensif $\left(\mathrm{T}_{2}\right)$ merupakan sistem pengolahan tanah yang dapat menghasilkan keanekaragaman mesofauna serasah lebih tinggi dibandingkan tanpa olah tanah $\left(\mathrm{T}_{0}\right)$ dan olah tanah minimum $\left(\mathrm{T}_{1}\right)$ (Tabel 6). Hal ini diduga karena

Tabel 2. Uji korelasi variabel pendukung dengan populasi dan Indeks Keanekaragaman (H') mesofauna serasah sebelum tanam (awal).

\begin{tabular}{lcc}
\hline \multirow{2}{*}{ Variabel } & \multicolumn{2}{c}{ Nilai $\mathrm{r}$} \\
\cline { 2 - 3 } & $\begin{array}{c}\text { Populasi } \\
\text { Mesofauna }\end{array}$ & $\begin{array}{c}\text { Indeks } \\
\text { Keanekaragaman }\left(\mathrm{H}^{\prime}\right)\end{array}$ \\
\hline $\begin{array}{l}\text { Biomassa } \\
\text { Serasah }\end{array}$ & $0,73^{\mathrm{tn}}$ & $0,05^{\mathrm{tn}}$ \\
pH Tanah & $0,36^{\mathrm{tn}}$ & $-0,21^{\mathrm{tn}}$ \\
$\begin{array}{l}\text { Kadar Air } \\
\text { Tanah }\end{array}$ & $0,72^{\mathrm{tn}}$ & $-0,27^{\mathrm{tn}}$ \\
Suhu & $-0,88^{*}$ & $0,49^{\mathrm{tn}}$ \\
Tanah & & \\
\hline
\end{tabular}

Keterangan : $*$ berbeda nyata pada taraf $5 \%$ dan $\operatorname{tn}=$ tidak berbeda nyata pada taraf $5 \%$.

Tabel 3. Analisis ragam pengaruh sistem olah tanah dan pemupukan nitrogen terhadap populasi mesofauna dan biomassa serasah setelah panen (akhir).

\begin{tabular}{lcc}
\hline \multicolumn{1}{c}{ Variabel } \\
Pengamatan & $\begin{array}{c}\text { Populasi } \\
\text { Mesofauna } \\
\text { Serasah }\end{array}$ & $\begin{array}{c}\text { Biomassa } \\
\text { serasah }\left(\mathrm{g} \mathrm{m}^{-2}\right)\end{array}$ \\
\hline Olah Tanah $(\mathrm{T})$ & $* *$ & $* *$ \\
Pemupukan & $*$ & $* *$ \\
Nitrogen $(\mathrm{N})$ & tn & tn \\
T x N &
\end{tabular}

Keterangan : $*$ berbeda nyata pada taraf $5 \% ; * *=$ berbeda nyata pada taraf $1 \%$; $\mathrm{tn}=$ tidak berbeda nyata pada taraf $5 \%$. 
Tabel 4. Uji lanjut BNT taraf 5\% sistem olah tanah dan pemupukan nitrogen terhadap populasi mesofauna serasah dan biomassa serasah $\left(\mathrm{g} \mathrm{m}^{-2}\right)$ setelah panen (akhir).

\begin{tabular}{llc}
\hline \multicolumn{1}{c}{ Perlakuan } & \multicolumn{1}{c}{$\begin{array}{c}\text { Populasi Mesofauna Serasah } \\
\left(\text { ekor } 100 \mathrm{~g}^{-1} \text { serasah }\right)\end{array}$} & $\begin{array}{c}\text { Biomassa serasah } \\
\left(\mathrm{g} \mathrm{m}^{-2}\right)\end{array}$ \\
\hline Tanpa olah tanah & $904(34) \mathrm{c}$ & $475 \mathrm{c}$ \\
Olah tanah minimum & $811(28) \mathrm{b}$ & $281 \mathrm{~b}$ \\
Olah tanah intensif & $209(14) \mathrm{a}$ & $159 \mathrm{a}$ \\
\hline BNT $_{0,05}$ & 4 & 52 \\
\hline Tanpa pemupukan nitrogen & $1123(22) \mathrm{a}$ & $268 \mathrm{a}$ \\
Pemupukan nitrogen $\left(100 \mathrm{~kg} \mathrm{~N} \mathrm{ha}^{-1}\right)$ & $1519(30) \mathrm{b}$ & $342 \mathrm{~b}$ \\
\hline BNT $_{0,05}$ & 5 & 63 \\
\hline
\end{tabular}

Keterangan : Angka yang diikuti huruf berbeda, berbeda nyata pada taraf 5\% uji BNT. Angka dalam kurung merupakan hasil transformasi $(\sqrt{ } \mathrm{x})$.

perbedaan komposisi atau jenis serasah. Pada olah tanah intensif (OTI) terdapat serasah tanaman padi gogo (Oryza sativa L.), dan beberapa jenis gulma diantaranya babandotan (Ageratum conyzoides), kentangan (Borreria alata), daun bergigi (Hyptis spc), dan kate mas (Euphorbia gemiculata). Pada lahan tanpa olah tanah (TOT) dan olah tanah minimum (OTM) jenis serasah pada lahan tersebut tidak begitu beragam, diantaranya serasah tanaman jagung (Zea mays), serasah tanaman padi gogo (Oriza sativa L.), alangalang (Imperata cylindrica), dan king grass (Setaria spc) (Utomo, 2012). Keanekaragaman gulma yang ditemukan pada olah tanah intensif disebabkan oleh keadaan tanah yang sering diolah dan dalam keadaan terbuka (tanpa mulsa).

Seperti saat sebelum tanam (awal), kategori Indeks Keanekaragaman (H') mesofauna serasah berdasarkan kategori Shannon-Weaver, semua perlakuan termasuk dalam kategori rendah (Tabel 7). Hal ini diduga karena ekosistem yang kurang seimbang. Hal tersebut juga dikatakan oleh Foth (1998) bahwa tingkat keragaman mesofauna ditentukan oleh ketersediaan energi dan kapasitas ekologi lingkungan. Hal tersebut sesuai dengan hasil penelitian Ricardo (2015) yang menyatakan bahwa kategori keanekaragaman mesofauna rendah pada lahan terganggu yakni pada lahan pertanian yang digunakan secara intensif dibandingkan lahan pertanian yang baru dibuka dan padang rumput alami.

Pada lahan penelitian, dilakukan analisis beberapa sifat fisik dan kimia contoh tanah maupun serasah setelah panen (akhir). Hasil analisis $\mathrm{pH}$ tanah memberikan rentang pH 5-6 dan kadar air tanah yang didapatkan berkisar 4-5 \%, sedangkan suhu tanah yang didapatkan berkisar $29-31{ }^{\circ} \mathrm{C}$. Perbandingan $\mathrm{C}$-organik serasah yang didapatkan termasuk tinggi dibandingkan $\mathrm{N}$-total
Tabel 5. Analisis ragam pengaruh sistem olah tanah dan pemupukan nitrogen terhadap Indeks Keanekaragaman $\left(\mathrm{H}^{\prime}\right)$ mesofauna serasah setelah panen (akhir).

\begin{tabular}{lc}
\hline Variabel Pengamatan & $\begin{array}{c}\text { Indeks } \\
\text { Keanekaragaman }\left(\mathrm{H}^{\prime}\right) \\
\text { Mesofauna Serasah }\end{array}$ \\
\hline Olah Tanah (T) & $*$ \\
Pemupukan Nitrogen $(\mathrm{N})$ & tn \\
T x N & tn \\
\hline
\end{tabular}

Keterangan : *= berbeda nyata pada taraf $5 \%$ dan $\mathrm{tn}=$ tidak berbeda nyata pada taraf $5 \%$.

Tabel 6. Uji lanjut BNT taraf 5\% antara sistem olah tanah dan Indeks Keanekaragaman (H') mesofauna serasah setelah panen (akhir).

\begin{tabular}{lc}
\hline \multicolumn{1}{c}{ Perlakuan } & $\begin{array}{c}\text { Indeks Keanekargaman } \\
\left(\mathrm{H}^{\prime}\right) \text { mesofauna serasah }\end{array}$ \\
\hline Tanpa olah tanah & $0,83 \mathrm{a}$ \\
Olah tanah minimum & $0,86 \mathrm{a}$ \\
Olah tanah intensif & $0,97 \mathrm{~b}$ \\
\hline BNT $_{0,05}$ & 0,06 \\
\hline
\end{tabular}

Keterangan : Angka yang diikuti huruf yang sama, tidak berbeda nyata pada taraf 5\% uji BNT.

serasah, sehingga rata-rata $\mathrm{C} / \mathrm{N}$ rasio serasah tergolong tinggi. Hal tersebut menunjukkan bahwa tingkat dekomposisi serasah terjadi lebih lama atau lambat. Hasil uji korelasi menunjukkan bahwa biomassa serasah berkorelasi positif dengan populasi mesofauna serasah, namun berkorelasi negatif dengan Indeks Keanekaragaman (H') mesofauna serasah (Tabel 8). Hal ini diduga karena biomassa serasah merupakan 
Tabel 7. Indeks Keanekaragaman (H') mesofauna serasah setelah panen (akhir).

\begin{tabular}{ccc}
\hline Perlakuan & Indeks Keanekaragaman $\left(\mathrm{H}^{\prime}\right)$ & Kategori (Shannon-Weaver) \\
\hline $\mathrm{T}_{0} \mathrm{~N}_{0}$ & $0,83 \pm 0,09$ & Rendah \\
$\mathrm{T}_{0} \mathrm{~N}_{1}$ & $0,83 \pm 0,10$ & Rendah \\
$\mathrm{T}_{1} \mathrm{~N}_{0}$ & $0,86 \pm 0,14$ & Rendah \\
$\mathrm{T}_{1} \mathrm{~N}_{1}$ & $0,87 \pm 0,06$ & Rendah \\
$\mathrm{T}_{2} \mathrm{~N}_{0}$ & $1,02 \pm 0,08$ & Rendah \\
$\mathrm{T}_{2} \mathrm{~N}_{1}$ & $0,91 \pm 0,12$ & Rendah \\
\hline
\end{tabular}

Keterangan : $\mathrm{T}_{0}=$ tanpa olah tanah $(\mathrm{TOT}), \mathrm{T}_{1}=$ olah tanah minimum $(\mathrm{OTM}), \mathrm{T}_{2}=$ olah tanah intensif (OTI), $\mathrm{N}_{0}=$ tanpa pupuk $\mathrm{N}, \mathrm{N}_{1}=$ pemupukan $\mathrm{N} 100 \mathrm{~kg} \mathrm{~N} \mathrm{ha}^{-1}$.

Tabel 8. Uji korelasi variabel pendukung dengan populasi dan Indeks Keanekaragaman (H') mesofauna serasah setelah panen (akhir).

\begin{tabular}{lcc}
\hline \multirow{2}{*}{ Variabel } & \multicolumn{2}{c}{ Nilai r } \\
\cline { 2 - 3 } & Populasi Mesofauna & Indeks Keanekaragaman $\left(\mathrm{H}^{\prime}\right)$ \\
\hline Biomassa Serasah $^{(\mathrm{x})}$ & $0,72^{* *}$ & $-0,54^{* *}$ \\
C-Organik Serasah $^{(\mathrm{y})}$ & $-0,12^{\mathrm{tn}}$ & $0,37^{\mathrm{tn}}$ \\
N-Total Serasah $^{(\mathrm{y})}$ & $-0,05^{\mathrm{tn}}$ & $0,41^{\mathrm{tn}}$ \\
C/N Ratio Serasah $^{(\mathrm{y})}$ & $-0,29^{\mathrm{tn}}$ & $0,04^{\mathrm{tn}}$ \\
pH Tanah $^{\left({ }^{\mathrm{n}}\right)}$ & $-0,32^{\mathrm{tn}}$ & $0,07^{\mathrm{tn}}$ \\
Kelembaban Tanah $^{(\mathrm{x})}$ & $0,53^{* *}$ & $0,29^{\mathrm{tn}}$ \\
Suhu Tanah $^{(\mathrm{x})}$ & $-0,22^{\mathrm{tn}}$ & $-0,19^{\mathrm{tn}}$ \\
\hline
\end{tabular}

Keterangan : $* *=$ berbeda nyata pada taraf $1 \%$ dan $\operatorname{tn}=$ tidak berbeda nyata pada taraf $5 \% . \mathrm{x}=$ $(\mathrm{n})=24$ dan $\mathrm{y}=(\mathrm{n})=6$.

substrat dan sumber energi bagi mesofauna, sehingga semakin banyak ketersediaan substrat dan sumber makanan maka semakin padatnya populasi mesofauna yang didapatkan. Banyaknya sumber makanan yang tersedia belum tentu memberikan keanekaragaman yang tinggi karena keanekaragaman mesofauna ditentukan oleh komposisi dan jenis serasah. Hal tersebut juga dikemukakan oleh Suin (2003), komposisi atau jenis serasah daun menentukan jenis mesofauna, sedangkan banyaknya serasah yang tersedia menentukan kepadatan mesofauna. Hasil uji korelasi menunjukkan bahwa kadar air tanah setelah panen berkorelasi positif dengan populasi mesofauna serasah setelah panen (Tabel 8). Hal ini diduga karena kelembaban yang tinggi merupakan faktor lingkungan yang mendukung bagi mesofauna untuk tumbuh dan berkembangbiak. Ratarata kadar air tanah setelah panen yaitu $5 \%$. Keadaan lahan akan semakin lembab dengan adanya mulsa yang menutupi permukaan tanah. Hal ini sesuai dengan hasil penelitian Camila (2012) yang menyatakan bahwa mesofauna ditemukan lebih banyak pada Hutan Basah Brazil Tenggara yang kelembabannya lebih tinggi daripada Hutan Semi-Gugur Brazil Tenggara. Lebih lanjut, hasil uji korelasi menunjukkan bahwa pH tanah, suhu tanah, C-organik serasah, N-total serasah, dan C/ $\mathrm{N}$ rasio serasah setelah panen (akhir) tidak berpengaruh dengan populasi maupun Indeks Keanekaragaman (H') mesofauna serasah setelah panen (akhir) (Tabel 8).

\section{KESIMPULAN}

Kesimpulan yang diperoleh dari hasil penelitian ini adalah populasi mesofauna serasah pada lahan tanpa olah tanah $\left(\mathrm{T}_{0}\right)$ lebih tinggi daripada olah tanah minimum $\left(\mathrm{T}_{1}\right)$ dan olah tanah intensif $\left(\mathrm{T}_{2}\right)$, sedangkan keanekaragaman mesofauna lebih tinggi pada olah tanah intensif $\left(\mathrm{T}_{2}\right)$ daripada tanpa olah tanah $\left(\mathrm{T}_{0}\right)$ dan olah tanah minimum $\left(\mathrm{T}_{1}\right)$. Populasi mesofauna serasah dengan pemupukan nitrogen $100 \mathrm{~kg} \mathrm{~N} \mathrm{ha-1}\left(\mathrm{N}_{1}\right)$ lebih tinggi daripada tanpa pemupukan nitrogen $\left(\mathrm{N}_{0}\right)$, sedangkan pemupukan nitrogen $100 \mathrm{~kg} \mathrm{~N} \mathrm{ha}^{-1}$ tidak berpengaruh terhadap keanekaragaman mesofauna serasah. Tidak terdapat interaksi antara sistem pengolahan tanah dan pemupukan nitrogen terhadap populasi dan keanekaragaman mesofauna serasah. (4) Indeks Keanekaragaman (H') mesofauna serasah pada seluruh perlakuan menurut kategori Shannon-Weaver termasuk dalam kategori rendah dan Acarina merupakan 
ordo mesofauna yang mendominasi. (5) Peningkatan biomassa serasah dapat meningkatkan populasi mesofauna serasah, namun menurunkan Indeks Keanekaragaman (H') mesofauna serasah. Selain itu, peningkatan kadar air tanah juga dapat meningkatkan populasi mesofauna serasah.

\section{DAFTAR PUSTAKA}

Borror, D. J., C. A. Triplehon, dan N. F. Johnson. 1997. Pengenalan Pelajaran Serangga. Gadjah Mada University Press. Yogyakarta. 1083 hal.

Camila T. C., L. Lorenzo, dan A. A. D. Oliveira. 2012. The importance of mesofauna and decomposition environment on leaf decomposition in three forests in Southeastern Brazil. J.Plant Ecology 213(8): 1303-1313.

Foth, H. D. 1998. Dasar-Dasar Ilmu Tanah. Gadjah Mada University Press. Yogyakarta. $782 \mathrm{hlm}$.

Gede, C.W.M. 2006. Pengaruh Pemberian Limbah Cair Pengolahan Minyak Kelapa Sawit (Elaeis gueneensis Jack) terhadap Populasi dan Keanekaragaman Mesofauna Tanah di PTP Nusantara VII (Persero) Unit Usaha Bekri Lampung Tengah. Skripsi. Universitas Lampung. Bandar Lampung. $41 \mathrm{hlm}$.

Guevara R., L. Villedo, dan A. Najera. 2002. Soil mesofauna patterns and experiments on leaf litter mite fungivory: preferences, effects on fungal reproduction and decomposition. Jurnal Acta Zoologica Mexicana 87: 1-15.

Nelfa, F. 2000. Keanekaragaman Mesofauna Tanah pada beberapa Penutupan Lahan di Kampus IPB
Darmaga. Skripsi. Institut Pertanian Bogor. Bogor.

Niswati, A., S. G. Nugroho, Dermiyati, S. Yusnaini, dan M.A.S. Arif. 2013. Penuntun Praktikum Biologi Tanah dan Kesehatan Tanah. Universitas Lampung. Bandar Lampung. $30 \mathrm{hlm}$.

Odum, E. P. 1983. Dasar-Dasar Ekologi. Edisi ketiga. Terjemahan Tjahjono Samingan. Gadjah Mada University Press. Yogyakarta. 697 hlm.

Prasetyo, Y.T. 2007. Bertanam Padi Gogo Tanpa Olah Tanah. Penebar Swadaya. Jakarta. $71 \mathrm{hlm}$.

Ricardo A.C.H., 1.B. Falco, R.V. Sandler, dan C.E. Coviella.2015. Differential contribution of soil biota groups to plant litter decomposition as mediated by soil use. J PeerJ 3(826) : 11-25.

Suin, N.M. 2003. Ekologi Hewan Tanah. Bumi Aksara. Jakarta. 22-24 hlm.

Sugiyarto, M. Pujo, dan N. S. Miati. 2001. Hubungan keragaman mesofauna tanah dan vegetasi bawah pada berbagai jenis tegakan di hutan Jobolarangan. Jurnal Biodiversitas 2 (2) : 140145.

Utomo, M. 2012. Tanpa Olah Tanah (Teknologi Pengelolaan Pertanian Lahan Kering). Lembaga Penelitian Universitas Lampung. Bandar Lampung. $110 \mathrm{hlm}$.

Yudin, S. 2012. Pengaruh Sistem Olah Tanah dan Aplikasi Mulsa Bagas Terhadap Populasi dan Biomassa Cacing Tanah Serta Populasi dan Keanekaragaman Mesofauna Tanah Pada Lahan Pertanaman Tebu. Skripsi. Universitas Lampung. Bandar Lampung. $67 \mathrm{hlm}$. 